\title{
Job Insecurity and Burnout among Teachers in Turkey
}

\author{
Cemile Çetin, Assistant Professor \\ Faculty of Economics and Administrative Sciences \\ Dokuz Eylul University, İzmir, Turkey \\ E-mail: cemilegurcay@gmail.com \\ Murat Çolak, Associate Professor \\ Faculty of Economics and Administrative Sciences \\ Dokuz Eylul University, İzmir, Turkey \\ E-mail:colak@muratcolak.com
}

Received: April 19, 2020 Accepted: May 11, 2020 Online published: May 18, 2020

doi:10.5296/ijhrs.v10i2.17053ＵRL: https://doi.org/10.5296/ijhrs.v10i2.17053

\begin{abstract}
In personal perceptions and evaluations, job insecurity is one of the facts that threaten employment and assurance to stay at work as a result of the ever-changing conditions of working life beyond finding a job. The negative results of the processes that cannot be coped with in the working life also constitute burnout. Like job insecurity, burnout emerges as a multi-dimensional and chronic response of personalized and failed efforts to manage various negative stress conditions. The purpose of this study is to examine the relationship between job insecurity and burnout. The hypothesis of the research was tested on 224 teachers working in the public sector. In addition, the sample group was asked if they had experienced unemployment and life changes that occurred when they experienced unemployment were also determined. The results of the study confirmed the relationship between job insecurity and burnout and revealed that teachers were less affected by burnout as their employability increased.
\end{abstract}

Keywords: job security, Job insecurity, burnout

\section{Introduction}

Working life and owned job are a central tool for most people, both in meeting economic and social needs and in building a source of income, social connections and an identity, among other characteristics. 
With its qualitative and quantitative diversity, the change affects every slice of life more intensely than in the past and continues to shape human processes - directly or indirectly, today or tomorrow, more or less, with problem-focused thinking or solution-focused thinking. As a matter of fact, the effect of the change on the individual's subjective areas is shaped by experiences and determines the emotional, intellectual, behavioral and psychological responses and their levels and the consequences that may arise. At this point, especially in recent years, the change in working life and elements of working life have led to intensive researches focusing on new concepts and practices related to work life. One of these concepts is job insecurity, which arises due to the change in employment practices and whose impact on working life increases with each passing day. Job insecurity affects all aspects of working life and has critical importance and priority, especially in terms of being both initiating and increasing burnout, another concept of working life. One of the main points that should not be overlooked is that both job insecurity and burnout are personal based on perceptual evaluations.

The relationship between job insecurity and burnout, the results of which are based on individual perception, evaluation and experiences in changing conditions of the working life, constitute the main subject of the study, and the results based on an application were evaluated and recommendations are offered.

\section{Theoretical and Conceptual Background}

\subsection{Job Insecurity}

Job insecurity has emerged as a new and vital phenomenon in the changing outlook of working life under intensely competitive conditions. Some of the reasons for this formation; organizations' obligation to reduce production costs and become more flexible in an intense competitive environment, new technologies require an increasing number of qualified employees and orientation of the industrial structure from production to service, etc.. In these conditions, organizations had two alternatives to be more profitable and to increase their earnings and reduce their costs for sustainable living conditions (Sverke and Hellgren, 2002: 25). Numerous organizations choose to reduce the number of employees at large as well as restructuring to increase their organizational effectiveness and competitiveness and reduce their costs. These developments, which were created as a solution, brought increasingly precarious employment and job insecurity. Job insecurity is related to control perceptions of threats, opportunities and individuals' job responsibilities. When threats are perceived as greater than opportunities, job insecurity will occur. Job insecurity, on which De Witte (2005:1) expressed that it is positioned between employment and unemployment, and that from this position workers have a sense of being threatened with unemployment, also leads the employees to give negative reactions due to the changes in their jobs (Sverke and Hellgren, 2002: 26).

With no clear definition of what "job insecurity" actually is, Rosenblatt and Ruvio refer to it as "anxiety about the future existence of the job", while Heaney and his colleagues considered it as "threats to the continuity of the job" (Sverke and Hellgren, 2002: 26). In one of their definitions, Sverke et al (2006: 5) stated "the subjectively experienced anticipation of 
a fundamental and involuntary event".

Job insecurity, which has antecedents focused on personal circumstances and assessments, was evaluated in the context of age, gender, personality, socio-economic status, type of employment contract and social support in the emphasis of Sverke et al. (2006: 9-11).

In the age context, people in their 30 s and 40 s are more concerned about job insecurity than those who bear only their own responsibility because they have responsibilities such as raising children. However, different studies have also found evidence that older employees may experience higher levels of job insecurity (Sverke et al., 2006: 9). Similarly, in a study conducted in Chile, it was observed that the age factor played an important role in employees with high-perceived employability, but did not affect employees with low perceived employability. Perceived employability in older workers does not reduce the negative consequences of job insecurity (Yeves et al., 2019: 6-10). In another study, the relationship between job insecurity and turnover intention was found to be higher in older employees than in younger ones (Cheng and Chan, 2007: 272).

In gender assessments, it was found that men tend to experience higher levels of job insecurity than women. This is mainly due to its traditional role. However, some studies also provide empirical evidence that women experience higher levels of job insecurity than men (Sverke et al., 2006: 9). Since women have higher rates of temporary employment than men and are exposed to discrimination in the labor market, they are more affected by job insecurity and its negative consequences than men (Laszlo et al., 2010: 868). In a study conducted in South Wales, it was stated that there are gender differences in their experiences and perceptions of job insecurity. In the same study, it was also stated that women feel less insecure than men and this is the result of men's responsibility to earn bread (Charles and James, 2003: 531). In a study conducted with temporary workers, no difference was found between male and female employees in perceived job insecurity (Giunchi et al., 2016: 12).

In the studies on the relationship between personality and job insecurity, it was concluded that people with predominantly external control focus experience higher levels of job insecurity. In contrast, there are also studies in which the results of high self-esteem and low job insecurity are related (Sverke et al., 2006: 9-10).

Socio-economic status can affect an individual's experience with job insecurity and lead to the conclusion that the job is under threat. The socio-economic situation is linked to the quality of the job and the level of education. People with low-status jobs and low incomes are often more dependent on their income and are therefore generally considered to be more vulnerable to the threat of job loss. A person with low income is often unable to accumulate, which can make the loss of income more serious. Research also shows that blue-collar workers experience higher levels of job insecurity than other categories of employees (Sverke et al., 2006: 10).

A certain type of employment contract can also affect perceptions of job insecurity. Employees hired on full-time or permanent contracts may experience less job insecurity. These employees may have a greater understanding of being an integral part of the 
organization than part-time or temporary employees. Studies exploring experiences of job insecurity among temporary workers typically reveal that employees with a time limit contract experience more job insecurity than permanent or full-time employees. Similarly, part-time workers experience higher levels of job insecurity than full-time workers (Sverke et al., 2006: 10-11).

It was determined that people who can get support from others within the scope of social support have lower job insecurity. Social support resources are defined as family and union membership (Sverke et al., 2006: 11; Bender and Sloane, 1999: 123). It was stated that the negative consequences of job insecurity for single people are more than married or living together. The reason for this is that the social and financial support of the spouse has a significant protective effect (Laszlo et al., 2010: 868).

\subsection{Burnout}

Burnout, which can be defined as a condition caused by the continuous discharge of a person's energy resources, has the characteristics of physical and psychological fatigue, emotional exhaustion, cognitive fatigue, sleep disorders, depression, and anxiety symptoms. Maslach initially defined burnout as a job-related condition and specifically addressed emotional labor-intensive jobs. The concept of burnout has been extended to include all professions from this approach (Norlund et al., 2010: 1-2).

Psychoanalyst Freudenberger published one of the first scientific definitions of burnout syndrome as psychiatric and physical impairment. In 1981, Maslach created a further definition and a tool by creating the Maslach Burnout Inventory, which is still the most commonly used in burnout measurement today. According to one of Maslach and Jackson's first more comprehensive definitions, burnout is "the result of chronic stress that has not been successfully dealt with at work". It is characterized by exhaustion and depersonalization (negativity/cynicism) and is predominantly seen in professionals such as social workers, teachers, nurses, doctors, dentists. Contrary to previous observations about the epidemiology of burnout based on developments over time, it was also noted that burnout syndrome is not related to certain workplaces, conditions, gender or age (Weber and Jaekel-Reinhard, 2000: 512-513).

Burnout in the definition of Maslach is "a phenomenon that includes the concepts of emotional fatigue, loss of self and decrease of individual success" (Maslach et al., 2001: 399). Burnout is a long-term response to chronic emotional and interpersonal stresses at work. Exhaustion is defined by three dimensions of cynicism and professional disability. Burnout impairs both personal and social functionality. With the decrease in both physical and psychological health as well as the quality of work, it can create multi-faceted costs not only for the individual employee but also for all those affected by that person (Maslach and Leiter, 2016: 351).

In Kulkarni's definition, burnout is expressed as "the incompatibility between intention and reality at work" (2006: 10-13), while Sabbah evaluates it as "a mental state defined as the body's response to the failure of coping strategies used by the individual to manage stress at 
work" (2012: 644). Faber's clinical experience shows that burnout occurs in ways that can be classified based on individuals' coping with job-related tasks and their level of commitment. The "frenetic" subtype is characterised by investing a large amount of time in working. The "inefficiency" burnout subtype is influenced by the type of occupation and is seen in complacent, bored individuals who do not have the opportunity for personal development in their work. The "worn-out" subtype is characterised by the feeling of losing control over outcomes, the perceived lack of recognition of one's own efforts, and the giving up of responsibilities. The "worn-out" subtype is influenced by the rigidity of the organisational structure at work (Montero-Marín et al., 2011: 2). Schaufeli and Enzmann expressed burnout as a stress-related concept (Els et al., 2015: 2).

Burnout occurs both through personal evaluations and perceptions and can occur when organizational conditions are irresistible and unfair to the extent that they are irresistible by personal factors (For detailed information, see: Maslach et al., 2001: 410; Klarreich, 1993: 115; Demirci and Büyük, 2010: 249; Dikmetaş et al., 2011: 3; Keser, 2005: 79).

Some demographic variables, such as age, marital status, and gender, are associated with burnout, but these results are not definitive or mandatory between different studies.

In a study conducted by Calvert, Flynn, Fraser, and Long (1991), no significant relationship was found between age and burnout. A non-linear relationship between age and emotional exhaustion and total burnout was obtained in a study conducted to evaluate the relationship between age, gender and burnout interactions in a sample of Canadian employees. Considering the results from the gender variable, the level of burnout in men decreased with increasing age. This relationship was found to be dual-mode in women, with women aged 20-35 and over 55 having the highest level of burnout (Marchand et al., 2018: 405).

In a study conducted in Northern Sweden between the ages of 25-64 with a group of 1000 participants (497 women and 503 men), the high frequency of burnout was found to be $13 \%$. The level of burnout in both genders decreased with age. Women's level of education, socio-economic position, the purpose of work and working hours emerged as important. Socio-economic status has been associated with burnout, especially in women (Norlund et al., 2010: 1-9).

In a study conducted with 3591 women, it was concluded that approximately $21 \%$ of women experience high levels of burnout. Women who had high burnout compared to those with low burnout are more often younger, divorced, blue-collar workers, lower educated, foreigners, on unemployment/retirement/sick-leave and financially strained. It was also concluded that these people also used more medication and cigarettes, reported higher work demands and lower control/social support at work, more somatic problems (e.g. pain) and depression (Soares et al., 2007: 61).

In gender and age-focused study, a negative correlation was found between young women and burnout and a positive correlation between older women and burnout. In middle-age women, there was no relationship between burnout and age. In men, there is a positive relationship between middle-aged men and burnout, while there is no relationship between 
young and old men and burnout (Ahola et al., 2008: 263).

A study conducted with 157 professionals from special education colleges and companies that provide care services for people with disabilities found a significant relationship between gender and burnout and emotional exhaustion. No significant relationship was found between gender and depersonalization and gender and personal accomplishment. Levels of overall burnout and emotional exhaustion are higher in men. Similarly, a positive correlation was found between age and exhaustion and age and emotional exhaustion. The older professionals' burnout levels and emotional exhaustion are higher than other age groups. A relationship was found between marital status and depersonalization. No significant relationship was found between marital status and overall burnout and the other two sub-dimensions. Regarding the level of education, only professionals who had completed only basic education were more affected by burnout than those who had completed secondary and higher education (Llorent and Ruiz-Calzado, 2016: 3290-3293).

\subsection{The Relationship Between Job Insecurity and Burnout}

Job insecurity has the ability to create broad and lasting results on family and society, starting from the individual. Job insecurity, which leads to a decrease or loss of the sense of control in life and an increase in uncertainty, makes it impossible for employees to predict the future. It also concretely creates many negative consequences such as fear, anxiety and job loss. In this case, when employees are not sure about their jobs and their future in business life, they can behave like not taking new responsibilities and stopping learning personal and corporate new developments. This situation would be defined as "burnout", which psychiatrist Glen Gabbard describes as "erosion of the soul" in developments based on personal perception and evaluation (Paterson and Adams, 2011; 40). Therefore, the concepts of job insecurity and burnout have been examined in many studies within the cause-effect relationship.

In a study conducted with 146 people working in different processes in a financial institution and the Human Resources Department, it was found that job insecurity was significantly related with increased burnout. It was observed in this study that job insecurity also caused increased burnout and cynicism and decreased professional activity. It was also concluded that job insecurity has an important predictive feature about burnout at a rate of $28 \%$ (Bosman et al., 2005: 39).

A study conducted by Aybas et al (2015: 200) on 154 white-collar employees found a positive relationship between job insecurity and burnout. The results also support a regulatory role of employability between job insecurity and burnout. Accordingly, it was observed that as the employability perception of the employees increased, they were less affected by burnout.

In the study conducted by İsmail (2015: 269) with 172 private bank employees in Syria, a positive relationship was found between job insecurity and burnout and turnover intention. A similar result regarding the relationship between job insecurity and burnout was obtained in the research conducted by Dekker and Schaufeli (1995: 57) in a large organization carrying out public transportation in Australia.

In the study conducted by Oprea and Iliescu (2015: 232) with 150 employees working in the 


\section{Mll Macrothink}

International Journal of Human Resource Studies

ISSN 2162-3058

2020, Vol. 10, No. 2

IT industry, using structural equation models, they showed that the increasing challenging job demands, one of the four components of job crafting, mediates the relationship between burnout and job insecurity. Thus, the relationship between job insecurity and burnout was revealed. Similarly, in the study conducted with 320 managers in the United States, the effects of job insecurity on job attitudes (satisfaction), job behaviors (organizational citizenship behavior) and negative emotions (anxiety, anger, burnout) were examined and it was concluded that there were direct or indirect effects on negative emotions (William et al., 2010: 74).

A study with 98 married couples in an organization undergoing downsizing found a relationship between burnout and job insecurity. Besides, there was a direct relationship between job insecurity and burnout among husbands but not among wives (Westman et al., 2001: 467). Similarly, in a survey conducted by Çetin with 117 municipal police officers working in the Metropolitan Municipality, a positive directional and weak relationship was found between job insecurity and burnout (2015: 88).

\section{Methodology}

\subsection{Data and Sample}

In the literature on burnout, which emerged as a result of inadequacies in dealing with stress, studies mainly consisted of research conducted with service sector employees (teaching, banking, insurance, nursing, doctor, academia, etc.). Based on the service sector, the sample of the research consists of the teachers working in the schools under the responsibility area of the Buca District National Education Directorate of Izmir. A procedure based on the necessity of obtaining permission for research to be made for teachers also constitutes the limitation of the research.

\subsection{Analyses}

The main hypothesis of the research is structured as "there is a significant relationship between teachers' job insecurity and burnout." Accordingly, 254 questionnaire forms were distributed and 224 questionnaire forms were analyzed with a 92\% return rate. Statistical analysis of data from 224 teachers by qualitative and quantitative job insecurity and burnout relation survey was carried out using SPSS (Statistical Package for Social Sciences) 17.0 statistical program.

\subsection{Measures}

The job insecurity scale measures qualitative and quantitative job insecurity. The qualitative job insecurity scale is a 4-item scale developed by Isaksson, Hellgren and Pettersson (Hellgren et al., 1999: 185). The quantitative job insecurity scale is a 5-item scale developed by Ashford, Hellgren and De Witte (Sverke et al., 2004: 210).

The Oldenberg (OLBI) burnout scale consists of the 8-item exhaustion component of burnout and the 8 -item dismissal sub-dimension. The scale was developed by Demerouti and Ebbinghaus (Halbesleben and Demerouti, 2005: 210). 


\section{Ml Macrothink}

International Journal of Human Resource Studies

ISSN 2162-3058

2020, Vol. 10, No. 2

The answers given to two questions, "In which of the following situations did you experience significant and priority increase during your period of unemployment?" and "If you were unemployed, in which of the following situations would you experience an important and priority increase?" which were considered to be particularly important for the study, were also evaluated and interpreted. As a result of the analysis, acceptable Cronbach Alpha values of 0.836 for quantitative job insecurity, 0.691 for qualitative job insecurity, 0.760 for burnout and 0.622 for dismissal were reached.

\section{Results}

As seen in Table 1, 72.8\% (163 people) of the sample are women and $26.8 \%$ (60 people) are men. $10.7 \%$ of the teachers forming the sample are $22-29$ years old, $13.4 \%$ are $30-32$ years old, $28.6 \%$ are $33-39$ years old, $20.1 \%$ are $40-43$ years old and $24,6 \%$ are over the age of 44 .

Table 1. Distribution of participants in terms of some demographic variables

\begin{tabular}{|c|c|c|c|}
\hline \multirow{5}{*}{ Gender } & & Frequency & $\begin{array}{r}\text { Percentage } \\
\text { Distribution } \\
(\%)\end{array}$ \\
\hline & Female & 163 & 72,8 \\
\hline & Male & 60 & 26,8 \\
\hline & Unanswered & 1 & 0,4 \\
\hline & Total & 224 & 100 \\
\hline \multirow{7}{*}{ Age } & $22-29$ & 24 & 10,7 \\
\hline & $30-32$ & 30 & 13,4 \\
\hline & $33-39$ & 64 & 28,6 \\
\hline & $40-43$ & 45 & 20,1 \\
\hline & $\begin{array}{r}44 \text { years and } \\
\text { above }\end{array}$ & 55 & 24,6 \\
\hline & Unanswered & 6 & 2,7 \\
\hline & Total & 224 & 100 \\
\hline \multirow{4}{*}{ Marital status } & Married & 192 & 85,7 \\
\hline & Single & 30 & 13,4 \\
\hline & Unanswered & 2 & 0,9 \\
\hline & Total & 224 & 100 \\
\hline \multirow{7}{*}{ Education Status } & High school & 3 & 1,3 \\
\hline & University & 192 & 85,7 \\
\hline & Master & 24 & 10,7 \\
\hline & Doctorate & 2 & 0,9 \\
\hline & Unanswered & 3 & 1,3 \\
\hline & Total & 224 & 100 \\
\hline & Less than 1 year & 18 & 8 \\
\hline
\end{tabular}




\begin{tabular}{|c|c|c|c|}
\hline \multirow{7}{*}{$\begin{array}{l}\text { How long have you } \\
\text { been working at the } \\
\text { school you are } \\
\text { currently working? }\end{array}$} & Between 1-5 years & 101 & 45,1 \\
\hline & Between 6-10 years & 51 & 22,8 \\
\hline & Between 11-15 years & 31 & 13,8 \\
\hline & Between $16-20$ years & 13 & 5,8 \\
\hline & 21 years and over & 6 & 2,7 \\
\hline & Unanswered & 4 & 1,8 \\
\hline & Total & 224 & 100 \\
\hline \multirow{8}{*}{$\begin{array}{l}\text { What is your total } \\
\text { working time in } \\
\text { your profession? }\end{array}$} & Between $1-5$ years & 19 & 8,5 \\
\hline & Between 6-10 years & 56 & 25 \\
\hline & Between $11-15$ years & 59 & 26,3 \\
\hline & Between $16-20$ years & 48 & 21,4 \\
\hline & 21 years and over & 38 & 17,0 \\
\hline & Total & 220 & 98,2 \\
\hline & Unanswered & 4 & 1,8 \\
\hline & Total & 224 & 100 \\
\hline \multirow{6}{*}{$\begin{array}{l}\text { Have you worked } \\
\text { anywhere other } \\
\text { than teaching in } \\
\text { National } \\
\text { Education? }\end{array}$} & No & 138 & 61,6 \\
\hline & $\begin{array}{r}\text { I worked in a private } \\
\text { classroom }\end{array}$ & 32 & 14,3 \\
\hline & $\begin{array}{r}\text { I worked in a private } \\
\text { school }\end{array}$ & 19 & 8,5 \\
\hline & I did my own business & 21 & 9,4 \\
\hline & Unanswered & 14 & 6,3 \\
\hline & Total & 224 & 100 \\
\hline
\end{tabular}

When the answers given to the question to determine the marital status are examined, it is seen that $83.3 \%$ of the sample is married. At the level of education, the highest share is university graduates with a ratio of $85 \%$, and teachers with a graduate degree with a ratio of $10.7 \%$.

The answer given to the question "your working time in the school you are currently working in", is "working time between 1-5 years" and it represents the highest rate with 45.1 . "Working time between 6-10 years" represents the second-highest rate with $22.8 \%$. Total working time in professional life is $26.3 \%$ in the " $11-15$ years" option while $25 \%$ in the "6-10 years". Therefore, it may be inferred that a change of place is made in the teaching profession with an average appointment of 2 or 3 times.

$61.6 \%$ of the teachers who answered the question "Have you worked anywhere other than teaching in National Education?" with the answer "No" represent $2 / 3$ of the sample. The group, representing the remaining $32.1 \%$ and $1 / 3$ of the sample, later became a teacher in public schools. This situation supports the view that there is a transition to the public sector due to job security. 


\section{Macrothink}

International Journal of Human Resource Studies

ISSN 2162-3058

2020, Vol. 10, No. 2

$61.6 \%$ of teachers answered "No" to the question "Have you worked anywhere other than teaching in National Education?". It was stated by teachers that $14.3 \%$ of the teachers started in the private classroom and then switched to National Education, $8.5 \%$ of the teachers started in the private school and then switched to National Education, and $9.8 \%$ of the teachers did their own job and later switched to National Education. In the light of the evaluated information, it is observed that $22.8 \%$ of the teachers who participated in the survey first taught in the private sector and then started teaching in National Education. Besides, more than a quarter of the teachers were private and public teachers with a ratio of $84.4 \%$, while the remaining $9.8 \%$ were teachers who switched to teaching after doing their own work. The data support the view that there is a transition to National Education (in other words "public sector") due to job security.

Table 2. Distribution of the participants by the most recent reasons for changing jobs

\begin{tabular}{|c|c|c|c|}
\hline & & Frequency & $\begin{array}{r}\text { Percentage } \\
\text { Distribution } \\
(\%)\end{array}$ \\
\hline \multirow{9}{*}{$\begin{array}{l}\text { (If You Changed } \\
\text { the Job) } \\
\text { What is your last } \\
\text { reason for } \\
\text { changing jobs? }\end{array}$} & I did not change jobs & 152 & 67,9 \\
\hline & I got laid off & 7 & 3,1 \\
\hline & $\begin{array}{l}\text { Reasons caused by } \\
\text { co-workers }\end{array}$ & 7 & 3,1 \\
\hline & Reasons caused by job & 12 & 5,4 \\
\hline & $\begin{array}{ll}\text { Reasons caused by } \\
\text { Manager } \\
\text { management }\end{array}$ & 10 & 4,5 \\
\hline & Family reasons & 8 & 3,6 \\
\hline & Other & 26 & 11,6 \\
\hline & Unanswered & 2 & 0,9 \\
\hline & Total & 224 & 100 \\
\hline
\end{tabular}

As shown in Table 2, 67.9\% of the sample stated that they did not change jobs, while the remaining $31,2 \%$ stated that they changed jobs for various reasons. The answers given by the teachers to the "Other" option as the reason for changing jobs are "having children, changing the institution and transferring between institutions, wanting to be a civil servant (officer) in public, not liking the previous job and thinking that the teaching profession has better opportunities". This result is followed by work reasons with $5.4 \%$ and management and manager reasons with $4.5 \%$. 


\section{Macrothink}

Table 3. Distribution of Participants by State of Unemployment

\begin{tabular}{|l|r|r|r|}
\hline & & Frequency & $\begin{array}{l}\text { Percentage } \\
\text { Distribution } \\
(\%)\end{array}$ \\
\hline $\begin{array}{l}\text { Have you } \\
\text { experienced } \\
\text { unemployment? }\end{array}$ & Yes & 61 & 27,2 \\
\hline & No & 150 & 67 \\
\hline & Unanswered & 13 & 5,8 \\
\hline
\end{tabular}

$67 \%$ of the teachers stated that they did not experience unemployment and $27.2 \%$ stated that they experienced unemployment. In other words, approximately $1 / 4$ of the teachers who participated in the study experienced unemployment. The responses given to two questions, "In which of the following situations did you experience an important and priority increase during your unemployment period?" and "If you were unemployed, in which of the following situations would you experience an important and priority increase?", which are considered to be particularly important for this research conducted to examine teachers' burnout and job insecurity levels, are summarized in Table 4 and Table 5.

Table 4. In which of the following situations did you experience an important and priority increase during your unemployment period?

\begin{tabular}{|l|r|r|}
\hline & Frequency & $\begin{array}{r}\text { Percentage } \\
\text { Distribution (\%) }\end{array}$ \\
\hline Smoking & 16 & 7,1 \\
\hline Feeling family pressure & 11 & 4,9 \\
\hline Feeling social pressure & 7 & 3,1 \\
\hline Desire to be alone & 2 & 0,9 \\
\hline Health problems & 2 & 3,4 \\
\hline Alcohol use & 1 & 0,4 \\
\hline Time with the family & 6 & 2,7 \\
\hline Engaging in hobbies & 4 & 1,8 \\
\hline Time with friends & 3 & 1,3 \\
\hline Use of social media & 2 & 0,9 \\
\hline Internet use & 1 & 0,4 \\
\hline Unemployment was not & 1 & 0,4 \\
\hline problem & & \\
\hline Other & 3 & 1,3 \\
\hline Unanswered & 165 & 73,7 \\
\hline Total & 224 & 100 \\
\hline
\end{tabular}

The change in the emotions and habits of 59 of the 61 teachers who have experienced 
unemployment in this period are given in Table 4. The answers based on the question "If you were unemployed, in which of the following situations would you experience an important and priority increase?" are included in Table 5.

Table 5. If you were unemployed, in which of the following situations would you experience an important and priority increase?

\begin{tabular}{|l|l|l|}
\hline & Frequency & $\begin{array}{l}\text { Percentage } \\
\text { Distribution (\%) }\end{array}$ \\
\hline Smoking & 19 & 8,5 \\
\hline Feeling family pressure & 17 & 7,6 \\
\hline Health problems & 9 & 4,0 \\
\hline Feeling social pressure & 8 & 3,6 \\
\hline Alcohol use & 3 & 1,3 \\
\hline Time with the family & 36 & 16,1 \\
\hline Engaging in hobbies & 11 & 4,9 \\
\hline Time with friends & 4 & 1,8 \\
\hline Use of social media & 10 & 4,5 \\
\hline Mobile phone use & 3 & 1,3 \\
\hline Internet use & 1 & 0,4 \\
\hline Desire to be alone & 2 & 0,9 \\
\hline Unemployment was not the & 6 & 2,7 \\
\hline problem & & \\
\hline Other & 13 & 5,8 \\
\hline Unanswered & 82 & 36,6 \\
\hline Total & 224 & 100 \\
\hline
\end{tabular}

The increase in cigarette use for the group that has experienced unemployment ranks first with a rate of $7.1 \%$, while family pressure ranks second with a rate of $4.9 \%$. Social pressure ranks third with $3.1 \%$. The expression "time with the family", which can be classified as positive results of unemployment, is in fourth place with $2.7 \%$ for those who have experienced unemployment and "engaging in hobbies" ranks fifth.

For those who have not experienced unemployment, the result, which is thought to be in the first place in case of unemployment, is that the time spent with the family will increase with $16.1 \%$. For this group, second place is an increase in smoking use with $8.5 \%$ and third place is an increase in family pressure with $7.6 \%$.

The level of qualitative job insecurity is higher than both quantitative job insecurity and job insecurity, according to the results of descriptive statistics on mean and standard deviations of job insecurity and burnout and subscale scores. The averages of burnout and dismissal subscale are close to each other, and at the same time, burnout and dismissal sub-dimensions are below average. The highest average between burnout and its sub-dimensions belongs to 
the exhaustion sub-dimension.

Table 6. Descriptive statistics of scales and sub-dimensions

\begin{tabular}{|l|l|l|l|l|l|l|}
\hline $\begin{array}{l}\text { Dimensions } \\
\text { and Sub } \\
\text { dimensions }\end{array}$ & N & Minimum & Maximum & Average & $\begin{array}{l}\text { Standard } \\
\text { Deviation }\end{array}$ & Variance \\
\hline $\begin{array}{l}\text { Quantitative } \\
\text { Job Insecurity }\end{array}$ & 224 & 1 & 5 & 1,7411 & 0,93267 & 0,87 \\
\hline $\begin{array}{l}\text { Qualitative Job } \\
\text { Insecurity }\end{array}$ & 224 & 1 & 5 & 3,471 & 1,0547 & 1,112 \\
\hline Job Insecurity & 224 & 1 & 5 & 2,6049 & 0,72668 & 0,528 \\
\hline Exhaustion & 224 & 1 & 5 & 2,9227 & 0,79599 & 0,634 \\
\hline $\begin{array}{l}\text { Dismissal from } \\
\text { Work }\end{array}$ & 224 & 1 & 5 & 2,8488 & 0,67403 & 0,454 \\
\hline Burnout & 224 & 1,15 & 5 & 2,8421 & 0,65249 & 0,426 \\
\hline
\end{tabular}

According to Spearman's rank correlation analysis, there is a positive directional and weak $(, 319)$ relationship between job insecurity and burnout in the $99 \%$ confidence interval and the main hypothesis is accepted.

Table 7. Correlation analysis results of the scales

\begin{tabular}{l|r|r|r|r|r|}
\hline & $\begin{array}{r}\text { Qualitative } \\
\text { Job Insecurity }\end{array}$ & $\begin{array}{r}\text { Job } \\
\text { Insecurity }\end{array}$ & Exhaustion & $\begin{array}{r}\text { Dismissal } \\
\text { from Work }\end{array}$ & Burnout \\
\hline $\begin{array}{l}\text { Quantitative } \\
\text { Job Insecurity }\end{array}$ & 0,061 & $0,650(* *)$ & $0,297(* *)$ & $0,143(*)$ & $0,261(* *)$ \\
\hline $\begin{array}{l}\text { Qualitative } \\
\text { Job Insecurity }\end{array}$ & 1 & $0,762(* *)$ & 0,118 & $0,320(* *)$ & $0,244(* *)$ \\
\hline $\begin{array}{l}\text { Job Insecurity } \\
\text { Exhaustion }\end{array}$ & & & & & \\
\hline $\begin{array}{l}\text { Dismissal } \\
\text { from Work }\end{array}$ & & & & & \\
\hline
\end{tabular}

**Significant in $99 \%$ Confidence interval

*Significant in $95 \%$ Confidence interval

Increasing job insecurity as a stressor factor is directly related to burnout levels. There is a positive and moderately strong relationship between job insecurity and qualitative $(, 762)$ and quantitative (, 650) job insecurity sub-dimensions in the $99 \%$ confidence interval. The relationship between job insecurity and qualitative job insecurity is higher than quantitative 
job insecurity. There is a positive and strong relationship between the level of burnout and its sub-dimensions of exhaustion (0.887) and dismissal (868) in the 99\% confidence interval. This relationship is higher than the relationship with the sub-dimensions of job insecurity. There is a positive and moderate (,573) relationship between exhaustion and dismissal sub dimensions in the $99 \%$ confidence interval. Quantitative job insecurity has a positive and weak relationship between dismissal $(, 143)$ in the $95 \%$ confidence interval, exhaustion $(0,297)$ in the $99 \%$ confidence interval. Qualitative job insecurity is not related to burnout, it has a positive and weak relationship with dismissal $(, 320)$.

Table 8. Mann-Whitney u test for gender and unemployment

\begin{tabular}{|c|c|c|c|c|}
\hline \multicolumn{3}{|c|}{ Gender } & \multicolumn{2}{|c|}{ Unemployment } \\
\hline & $\mathrm{z}$ & $\mathrm{p}$ & $\mathrm{z}$ & $\mathrm{p}$ \\
\hline $\begin{array}{l}\text { Quantitative Job } \\
\text { Insecurity }\end{array}$ & $-0,889$ & 0,374 & $-0,183$ & 0,855 \\
\hline $\begin{array}{l}\text { Qualitative Job } \\
\text { Insecurity }\end{array}$ & $-2,015$ & 0,044 & $-0,308$ & 0,758 \\
\hline Job Insecurity & $-1,819$ & 0,069 & $-0,182$ & 0,856 \\
\hline Exhaustion & $-3,471$ & 0,001 & $-0,504$ & 0,614 \\
\hline $\begin{array}{l}\text { Dismissal from } \\
\text { Work }\end{array}$ & $-1,656$ & 0,098 & $-0,48$ & 0,631 \\
\hline Burnout & $-2,674$ & 0,008 & $-0,124$ & 0,901 \\
\hline
\end{tabular}

Whether job insecurity, burnout, and sub-dimensions differ or not by gender and state of unemployment was analyzed by the Mann-Whitney $U$ test. Burnout $(p=0,008<0,05)$, exhaustion $(\mathrm{p}=0,001<0,05)$ and qualitative job insecurity $(\mathrm{p}=0,044<0,05)$ differ significantly by gender. The average number of rows of female teachers regarding both burnout and exhaustion sub-dimension is higher than male teachers. Accordingly, female teachers are more prone to burnout and exhaustion as well as qualitative job insecurity than male teachers. In the sample, the level of job insecurity and burnout and subscales do not differ significantly from the state of experiencing unemployment. The average number of rows for teachers' unemployment and non-living situations is close to each other.

Table 9. Kruskal-wallis for age, education, marital status and professional seniority period

\begin{tabular}{|l|l|l|l|l|l|l|l|}
\hline \multicolumn{3}{|c|}{ Age } & & \multicolumn{3}{c|}{ Education } \\
\hline $\begin{array}{l}\text { Scales and Sub } \\
\text { Scales }\end{array}$ & Chi-square & df & $p$ & & Chi-square & df & $p$ \\
\hline $\begin{array}{l}\text { Quantitative Job } \\
\text { Insecurity }\end{array}$ & 2,386 & 1 & 0,665 & 0,758 & 3 & 0,859 \\
\hline Qualitative Job & 1,504 & 1 & 0,826 & 0,067 & 3 & 0,995 \\
\hline
\end{tabular}




\begin{tabular}{|c|c|c|c|c|c|c|}
\hline \multicolumn{7}{|l|}{ Insecurity } \\
\hline Job Insecurity & 1,457 & 1 & 0,887 & 0,343 & 3 & 0,952 \\
\hline Exhaustion & 9,578 & 1 & 0,048 & 5,529 & 3 & 0,137 \\
\hline $\begin{array}{l}\text { Dismissal from } \\
\text { Work }\end{array}$ & 0,446 & 1 & 0,979 & 1,645 & 3 & 0,649 \\
\hline Burnout & 3,426 & 1 & 0,489 & 3,459 & 3 & 0,326 \\
\hline \multicolumn{4}{|c|}{ Marital status } & \multicolumn{3}{|c|}{ Professional Seniority } \\
\hline $\begin{array}{l}\text { Scales and Sub } \\
\text { Scales }\end{array}$ & Chi-square & df & $\mathrm{p}$ & Chi-square & df & $\mathrm{P}$ \\
\hline $\begin{array}{l}\text { Quantitative Job } \\
\text { Insecurity }\end{array}$ & 0,335 & 1 & 0,859 & 5,801 & 4 & 0,214 \\
\hline $\begin{array}{l}\text { Qualitative Job } \\
\text { Insecurity }\end{array}$ & 0,55 & 1 & 0,995 & 4,117 & 4 & 0,39 \\
\hline Job Insecurity & 0,004 & 1 & 0,952 & 4,07 & 4 & 0,397 \\
\hline Exhaustion & 1,681 & 1 & 0,195 & 10,884 & 4 & 0,028 \\
\hline $\begin{array}{l}\text { Dismissal from } \\
\text { Work }\end{array}$ & 2,302 & 1 & 0,129 & 3,288 & 4 & 0,511 \\
\hline Burnout & 1,924 & 1 & 0,165 & 7,804 & 4 & 0,099 \\
\hline
\end{tabular}

According to the results in Table 9, while quantitative $(\mathrm{p}=0,665>0,05)$ and qualitative job insecurity $(\mathrm{p}=0,826>0,05)$, job insecurity $(\mathrm{p}=0,887>0,05)$, dismissal $(\mathrm{p}=0,979>0,05)$ and burnout $(\mathrm{p}=0,489>0,05)$ do not differ significantly by age, the exhaustion $(\mathrm{p}=0,048<0,05)$ sub-dimension shows a significant difference by age. The average number of rows of teachers between the ages of 40-43 is higher than the other age groups. According to the results obtained from the analysis of the educational status, job insecurity and burnout and sub-dimensions do not differ significantly from education. In terms of professional seniority, only exhaustion $(\mathrm{p}=0.028)$ shows a significant difference. While the average number of rows regarding the exhaustion level of teachers whose professional seniority is between 16-20 years is higher than the other periods; the average number of rows of teachers whose professional seniority is 21 years or more is the lowest. Job insecurity, burnout, and sub-dimensions do not differ significantly based on marital status. 


\section{I Macrothink}

Table 10. The situation of teaching or not teaching in the private sector

\begin{tabular}{|c|c|c|c|c|c|c|c|c|}
\hline $\begin{array}{l}\text { Scales and Sub } \\
\text { Scales }\end{array}$ & & $\mathrm{N}$ & Mean & $\mathrm{F}$ & Sig. & $\mathrm{t}$ & $\mathrm{df}$ & $\mathrm{P}$ \\
\hline \multirow{2}{*}{$\begin{array}{l}\text { Quantitative Job } \\
\text { Insecurity }\end{array}$} & No & 72 & 1,8472 & 4,706 & 0,031 & \multirow{2}{*}{$\begin{array}{l}1,27 \\
1,188\end{array}$} & \multirow{2}{*}{$\begin{array}{l}208 \\
120,083\end{array}$} & \multirow{2}{*}{$\begin{array}{l}0,205 \\
0,237\end{array}$} \\
\hline & Yes & 138 & 1,6739 & & & & & \\
\hline \multirow{2}{*}{$\begin{array}{l}\text { Qualitative Job } \\
\text { Insecurity }\end{array}$} & No & 72 & 3,3958 & 0,035 & 0,851 & \multirow{2}{*}{$\begin{array}{l}-0,901 \\
-0,896\end{array}$} & \multirow{2}{*}{$\begin{array}{l}208 \\
141,49\end{array}$} & \multirow{2}{*}{$\begin{array}{l}0,368 \\
0,372\end{array}$} \\
\hline & Yes & 138 & 3,5326 & & & & & \\
\hline \multirow[t]{2}{*}{ Job Insecurity } & No & 72 & 2,6146 & 0,471 & 0,493 & \multirow{2}{*}{$\begin{array}{l}0,089 \\
0,086\end{array}$} & \multirow{2}{*}{$\begin{array}{l}208 \\
131,527\end{array}$} & \multirow{2}{*}{$\begin{array}{l}0,929 \\
0,932\end{array}$} \\
\hline & Yes & 138 & 2,6051 & & & & & \\
\hline \multirow[t]{2}{*}{ Exhaustion } & No & 72 & 2,9322 & 1,219 & 0,271 & \multirow{2}{*}{$\begin{array}{l}0,227 \\
0,237\end{array}$} & \multirow{2}{*}{$\begin{array}{l}208 \\
162,423\end{array}$} & \multirow{2}{*}{$\begin{array}{l}0,821 \\
0,813\end{array}$} \\
\hline & Yes & 138 & 2,9063 & & & & & \\
\hline \multirow{2}{*}{$\begin{array}{l}\text { Dismissal from } \\
\text { Work }\end{array}$} & No & 72 & 2,8426 & 0,022 & 0,883 & \multirow{2}{*}{$\begin{array}{l}-0,087 \\
-0,088\end{array}$} & \multirow{2}{*}{$\begin{array}{l}208 \\
146,608\end{array}$} & \multirow{2}{*}{$\begin{array}{l}0,931 \\
0,93\end{array}$} \\
\hline & Yes & 138 & 2,8512 & & & & & \\
\hline \multirow[t]{2}{*}{ Burnout } & No & 72 & 2,8424 & 1,102 & 0,295 & \multirow{2}{*}{$\begin{array}{l}0,028 \\
0,029\end{array}$} & \multirow{2}{*}{$\begin{array}{l}208 \\
160,816\end{array}$} & \multirow{2}{*}{$\begin{array}{l}0,978 \\
0,977\end{array}$} \\
\hline & Yes & 138 & 2,8398 & & & & & \\
\hline
\end{tabular}

$\mathrm{P}<0,05$

The Independent-Samples t-test was used to test whether job insecurity and burnout and lower dimensions differ between those who teach in the private sector and those who don't. The average of job insecurity and quantitative job insecurity sub-dimension of those who do not teach in the private sector is higher than those who teach in the private sector, while the average of the qualitative job insecurity sub-dimension is lower. The average of the burnout and burnout sub-dimension of those who do not teach in the private sector is higher than those who teach in the private sector, while the average of the work-away sub-dimension is lower. But there is no meaningful difference between the averages of the two groups ' job insecurity, burnout, and lower dimensions.

\section{Conclusion}

Work is a central tool in meeting the economic and social needs for most people. Among other characteristics, it is a source of income, social connections, and identity. However, the changing nature of the work creates different concepts and results. One of them was job 
insecurity and burnout. Job insecurity can be defined as a function of both the objective situation (e.g. labor market characteristics, organizational change) and subjective characteristics of the person (e.g. family responsibility, employability), while burnout can be defined as the wear of the soul in its most general sense. Job insecurity and burnout have the potential to negatively affect the whole life.

The most striking point is the multiplicity and diversity of the number of variables that can be defined as the cause of both job insecurity and burnout. Job insecurity, which makes the impact on working life and employees more intense day by day, has become as important a problem as unemployment and continues. The existence of job insecurity undermines the employee's sense of self-confidence, which is one of the most basic tasks of working life, and thus can lead to chronic stress and then burnout, with results based on personal perception and evaluations.

At this point, the study aims to reveal the relationship between job insecurity and demographic variables with the burnout of teachers, who are made up of 224 people who work in the public sector. Within the sample limitation; There is a positive and weak $(, 319)$ relationship between job insecurity and burnout in the $99 \%$ confidence interval and the main hypothesis was accepted. Similarly, in a study by Bosman et al. the relationship between increased job insecurity and burnout as a creative factor burnout was found to occur as a result of long-term and significant job insecurity (Bosman et al., 2005: 48).

It was concluded that burnout, exhaustion, and qualitative job insecurity differ significantly by gender, by analyzing whether job insecurity and burnout and sub-dimensions differ according to gender and unemployment. Female teachers were found more prone to burnout and exhaustion as well as qualitative job insecurity compared to male teachers. Research by Decker and Borgen (1993) supports the importance of gender differences in burnout. Most studies show higher levels of emotional exhaustion among women and greater desensitization among men (Louw et al., 2011: 1-2). A similar result was found in Girgin's study carried out with 446 primary teachers in Buca district of Izmir province that female teachers' emotional burnout score averages were significantly higher than men (Girgin, 2011: 606). In the studies conducted by Aybas et al. (2015: 200) with white-collar employees, the result was that female employees experience more burnout than men. In another study, no significant relationship was found between the genders and burnout levels of teachers (Cemaloğlu and Şahin, 2007: 480).

In the study, a significant difference was found only in the burnout $(\mathrm{p}=0.048<0.05$ ) sub-dimension in age-related analyzes. Accordingly, the average number of rows of teachers between the ages of 40-43 is higher than the other age groups. In a similar result obtained in another research conducted with teachers, a significant relationship was found between age and burnout levels (Cemaloğlu and Şahin, 2007: 480). Research generally shows that young employees have a high susceptibility to burnout. Young teachers who are new to their profession tend to be idealistic and can often be very concerned about accomplishing their jobs professionally. When they are unable to reach their students, they can feel intense that both their loss of value and their performance are not appreciated, and they may be 
vulnerable to exhaustion by feeling more anxious and inadequate. Burke and Greenglass found in their study that age was not significant in teacher burnout (Louw et al., 2011: 2).

Another finding in the study was that job insecurity and burnout and sub-dimensions do not differ significantly in terms of marital status. There are different results in the researches on the relationship between marital status and burnout. Those who are not married (especially men) seem more prone to burnout than married ones. On the other hand, Sears and Navin did not find a significant relationship between marital status and burnout (Louw et al., 2011: 2). In their study, Maslach and Jackson (1981: 99-113) concluded that married individuals experience consistently less burnout than singles. A study with 111 married couples showed that the stress caused by job insecurity is negatively related to both spouses, marriage and family functions, regardless of employment status. Job insecurity stress was negatively related to marital adjustment, family communication, family problem solving, clarity of family roles and emotional participation. The stress of job insecurity of men in marriage has negatively affected their marital satisfaction, general family functions, the clarity of the family role and their perception of emotional sensitivity. They felt that family roles became less clear under the pressure of job insecurity (Larson et al., 1994: 141-142).

According to the results obtained from the analysis of the educational situation, job insecurity and burnout and sub-dimensions do not differ significantly from education. Similarly; in a study conducted by Tilakdharee et al. with employees in the education and development sector in 2010, it was concluded that there was no significant difference between job insecurity and burnout and its sub-dimensions according to age and education (263). Teachers with a high level of education tend to have higher expectations than they want to achieve, and failure to meet these expectations may cause them to be prone to burnout. Altun et al (2011) and Schaufeli and Enzmann (1998) found that employees with a high level of education were more prone to burnout (Louw et al., 2011: 2).

As for the results obtained in terms of professional seniority, only burnout $(p=0.028)$ shows a significant difference according to professional seniority. The average number of rows of teachers whose professional seniority is between 16 and 20 years is higher than the others. The average number of rows of teachers with professional seniority of 21 years and over is the lowest. In the study of Dolunay and Piyal (2003: 44) conducted with 1462 teachers in Keçiören District of Ankara, the result was that the overall burnout decreased and the sense of personal accomplishment increased as the total professional service time increased. In another study, it was concluded that there is a significant relationship between burnout and sub-dimensions according to professional seniority. While the average number of ranks in burnout and sub-dimensions of the participants whose professional seniority was between 11-15 years was highest, the participants with the professional seniority period between 1-5 years were at the lowest level (Tilakdharee et al., 2010: 265).

One of the results related to the sampling; the behaviors that people who have experienced unemployment and who have not experienced unemployment express that they will take priority in the individual and social consequences that may arise are smoking, family pressure and relationships with the family. These results support the negative consequences of job 


\section{Ml Macrothink}

International Journal of Human Resource Studies

ISSN 2162-3058

2020, Vol. 10, No. 2

insecurity in different studies (Tilakdharee et al., 2010: 256; Greenhalgh and Rosenblatt, 1984: 439; De Witte et al., 2010: 42; Meltzer et al., 2010: 1402).

The fact that social health is possible with personal and organizational health should not be ignored. Individuals adopt such proactive behavior in order to match their abilities and needs and thereby increase harmony between themselves and their environment. At this point, although it is not possible to reduce the effects of job insecurity in the short term, it can be important and priority to develop employability skills at the point of producing personal solutions. Business enrichment and coaching practices and individual-level regulations can contribute to achieving short- and medium-term positive results. Individual or group-based interventions (workshops) appear to be effective in reducing burnout, especially in the short term.

Organizations must take measures to prevent and manage the most negative impacts by providing accurate information, improving communication, providing retraining for alternative employment, and educating their employees to deal with the stress caused by both job insecurity and burnout.

In macro approaches; It is absolutely indispensable for the government to structure its employment policy, beyond legal regulation, as a priority of supervision and correction.

Systematic research, especially burnout, is needed regarding the consequences of job insecurity. The need for longitudinal studies on issues such as causality issues and the long-term effects of precariousness is greater than ever.

Further research is needed in each of the areas of individual differences, perceptions of justice and social support. Research highlighting the consequences of job insecurity and burnout of employees and strategies that organizations and unions can use to help cope practices is vital and a priority.

If a work-related insecurity and burnout-oriented value shift continues in business life, other connotations, such as ongoing job training, professional development, and future employability threats, may become increasingly ongoing. Interventions to alleviate burnout and reverse it should be carried out both on a corporate and personal level, with job security based on participation and commitment.

\section{References}

Ahola, K., Honkonen, T., Virtanen, M., Aromaa, A., \& Lönnqvist, J. (2008) Burnout in relation to age in the adult working population. Journal of Occupational Health, 50(4), 362-365. https://doi.org/10.1539/joh.M8002

Aybas, M., Elmas, S., \& Dündar, G. (2015). Job insecurity and burnout: The moderating role of employability. European Journal of Business and Management, 7(9), 195-202. ISSN 2222-1905 (Paper) ISSN 2222-2839 (Online). 
Bender, K. A., \& Sloane, P. J. (1999). Trade union membership, tenure and the level of job insecurity. Journal Applied Economics, 31(1), 123-135. https://doi.org/10.1080/000368499324615

Bosman, J., Buitendach, J. H., \& Laba, K. (2005). Job insecurity, burnout and organizational commitment among employees of a financal institution in Gauteng. SA Journal of Industrial Psychology, 31(4), 32-40. https://doi.org/10.4102/sajip.v31i4.210

Cemaloğlu, N., \& Şahin, D. E. (2007). Öğretmenlerin tükenmişlik düzeylerinin farklı değişkenlere göre incelenmesi. Kastamonu Eğitim Dergisi, 15(2), 465-484.

Çetin, C. (2015). Zabıta çalışanlarında iş güvencesizliği ile tükenmişlik ilişkisine yönelik bir araştırma. Celal Bayar Üniversitesi, Sosyal Bilimler Dergisi, 13(2), 73-95. https://doi.org/10.18026/cbusos.78112

Charles, N., \& James, E. (2003). The gender dimensions of job insecurity in a local labour market. Work, Employement, Society, 17(3), 531-552. https://doi.org/10.1177/ 09500170030173007

Cheng, G. H. L., \& Chan, D. K.S. (2007). Who suffers more from job insecurity? A meta-analytic review. Applied Psychology, 57(2), 272-303. https://doi.org/ 10.1111/j.1464-0597.2007.00312.x

De Witte, H. (2005). Job insecurity: Review of the international literature on definitions, prevalence, antecedents and consequences. SA Journal of Industrial Psychology, 31(4), 1-6. https://doi.org/10.4102/sajip.v31i4.200

De Witte, H., De Cuyper, N., Handaja, Y., Sverke, M., Näswall, K., \& Hellgren, J. (2010). Associations between quantitative and qualitative job insecurity and well-being. International Studies of Management \& Organization, 40(1), 40-56. https://doi.org/10.2753/ IMO0020-8825400103

Dekker, S. W., \& Schaufeli, W. B. (1995). The effects of job insecurity on psychological health and withdrawal: A longitudinal study. Australian Psychologist, 30, 57-63. https://doi.org/10.1080/00050069508259607

Demirci, M. K., \& Büyük, K. (2010). Mobbing: Duygusal taciz. In D. E. Özler(Ed.), Örgütsel davranışta güncel konular. Ekin Yayınevi.

Dikmetaş, E., Top, M., \& Ergin, G. (2011). Asistan hekimlerin tükenmişlik ve mobbing düzeylerinin incelenmesi. Türk Psikiyatri Dergisi, 22, 1-15.

Dolunay, A. B., \& Piyal, B. (2003). Öğretmenlerde bazı mesleki özellikler ve tükenmişlik. Kriz Dergisi, 11(1), 35-48.

Els, C., Mostert, K., \& De Beer, L. T. (2015). Job characteristics, burnout and the relationship with recovery experiences. SA Journal of Industrial Psychology, 41(1). Art. \#1196, 13 pages. http:// dx.doi.org/10.4102/sajip. v41i1.1196 
Girgin, G. (2011). Bir grup ilköğretim öğretmeninde tükenmişlik sendromu. Türkiye Klinikleri J Med Sci, 31(3), 602-608. https://doi.org/10.5336/medsci.2009-16135

Giunchi, M., Emanuel, F., Chambel, M. J., \& Ghislieri, C. (2016). Job insecurity, workload and job exhaustion in temporary agency workers (taws) gender differences. Career Development International, 21(1), 3-18. https://doi.org/10.1108/CDI-07-2015-0103

Greenhalgh, L., \& Rosenblatt, Z. (1984). Job insecurity: Toward conceptual clarity. The Academy of Management Review, 9(3), 438-448. https://doi.org/10.5465/amr.1984.4279673

Halbesleben, J. R. B., \& Demerouti, E. (2005). The construct validity of an alternative measure of burnout: Investigating the English translation of the Oldenburg Burnout Inventory. Work \& Stress, 19, 208-220. https://doi.org/10.1080/02678370500340728

Hellgren, J., Sverke, M., \& Isaksson, K. (1999). A two-dimensional approach to job insecurity: Consequences for employee attitudes and well-being. European Journal of Work and Organizational Psychology, 8(2), 179-195. https://doi.org/10.1080/135943299398311

İsmail, H. (2015). Job insecurity, burnout and intention to quit. International Journal of Academic Research in Business and Social Sciences, 5(4), 263-277. ISSN: 2222-6990. http://dx.doi.org/10.6007/IJARBSS/v5-i4/1574

Keser, A. (2005). İş doyumu ve yaşam doyumu ilişkisi: Otomotiv sektöründe bir uygulama. Çalışma ve Toplum, 3, 77-96.

Klarreich, H. S. (1993). Stressiz çalışma ortamı. Güngör, B. (Çev). Öteki Yayınevi, Ankara.

Kulkarni, G. K. (2006). Burnout. Indian Journal Occupational and Environmental Medicine, 10(1), 3-4. https://doi.org/10.4103/0019-5278.22887

Larson, J. H., Wilson, S. M., \& Beley, R. (1994). The impact of job insecurity on marital and family relationships. Family Relations, 43(2), 138-143. https://doi.org/10.2307/585315

Laszlo, K. D., Pikhart, H., Kopp, M. S., Bobak, M., Pajak, A., Malyutina, S., Salavecz, G., \& Marmot, M. (2010). Job insecurity and health: A study of 16 European Countries. Social Science \& Medicine, 70, 867-874. https://doi.org/10.1016/j.socscimed.2009.11.022

Llorent, V. J., \& Ruiz-Calzado, I. (2016). Burnout and its relation to sociodemographic variables among education professionals working with people with disabilities in Córdoba (Spain). Ciência $\quad \& \quad$ Saúde $\quad$ Coletiva, 21(10). 3287-3295. https://doi.org/10.1590/1413-812320152110.00732015

Louw, D. A., George, E., \& Esterhuyse, K. (2011). Burnout amongst urban secondary School teachers in Namibia. SA Journal of Industrial Psychology/SA Tydskrif vir Bedryfsielkunde, 37(1), 01-07. Art. \#1008. https://doi.org/10.4102/sajip.v37i1.1008

Marchand, A., Blanc, M. E., \& Beauregard, N. (2018). Do age and gender contribute to workers' burnout symptoms?. Occupational Medicine, 68, 405-411. Advance access publication 15 June.18. https://doi.org/10.1093/occmed/kqy088 


\section{Macrothink}

International Journal of Human Resource Studies ISSN 2162-3058 2020, Vol. 10, No. 2

Maslach, C., \& Jackson S. E. (1981). The measurement of experienced burnout. Journal of Occupational Behavior, 2, 99-113. https://doi.org/10.1002/job.4030020205

Maslach, C., Schaufeli, W. B., \& Leiter, M. P. (2001). Job burnout. Annual Reviews Psychology, 52, 397-422. https://doi.org/10.1146/annurev.psych.52.1.397

Maslach, C., ve Leiter, M. P. (2016). Stress: Concepts, cognition, emotion, and behavior. Handbook of Stress Series, 1, 351-357. https://doi.org/10.1016/B978-0-12-800951-2.00044-3

Meltzer, H., Bebbington, P., Brugnha, T., Jenkins, R., McManus, S., \& Stansfeld, S. (2010). Job insecurity, socio-economic circumstances and depression. Psychological Medicine, 40, 1401-1407. https://doi.org/10.1017/S0033291709991802

Montero-Marín, J., Skapinakis, P., Araya, R., Gili, M., \& García-Campayo, J. (2011). Towards a brief definition of burnout syndrome by subtypes: Development of the "Burnout Clinical Subtypes Questionnaire" (BCSQ-12). Health and Quality of Life Outcomes, 9(74), 1-12. https://doi.org/10.1186/1477-7525-9-74

Norlund, S., Reuterwall, C., Höög, J., Lindahl, B., Janlert, U., \& Birgander, L. S. (2010). Research article burnout, working conditions and gender - results from the northern Sweden MONICA study. BMC Public Health, 10, 326. https://doi.org/10.1186/1471-2458-10-326

Oprea, B., \& Iliescu, D. (2015). Burnout and job insecurity: The mediating role of job crafting. Human Resources Psychology, 13(2), 232-244. https://doi.org/10.1037/t01688-000

Paterson, R., \& Adams, J. (2011). Professional burnout - a regulatory perspective. NZ Med, 124(1333), 40-46.

Sabbah, I., Sabbah, H., Sabbah, S., Akoum, H., \& Droubi, N. (2012). Burnout among Lebanese nurses: Psychometric properties of The Maslach Burnout Inventory-Human Services Survey (MBI-HSS). Health, 4(9), 644-652. https://doi.org/10.4236/health.2012.49101

Soares, J. J. F., Grossi, G., \& Sundin, O. (2007). Burnout among women: Associations with demographic/socio-economic, work, life-style and health factors. Archieves of Women's Mental Health, 10(2), 61-71. https://doi.org/10.1007/s00737-007-0170-3

Sverke, M., \& Hellgren, J. (2002). The nature of job insecurity: Understanding employement uncertainty on the brik of a new millennium. Applied Psychology: An International Review, 51(1), 23-42. https://doi.org/10.1111/1464-0597.0077z

Sverke, M., Hellgren, J., \& Näswall, K. (2006). Job insecurity: A literature review. SALTSA, National Institute for Working Life and Authors. Report No 1. 1-30. ISSN: 1404-790X.

Sverke, M., Hellgren, J., Naswall, K., \& De Witte, H. (2004). Job insecurity and union membership: European unions in the wake of flexible production. SALTSA-Joint programme for working life research in Europe, The National Instute for Working Life and Swedish Trade Unions in Cooperation. Work \& Society, 42, Pres Interuniversitaires Europeennes. 


\section{Macrothink}

International Journal of Human Resource Studies

ISSN 2162-3058 2020, Vol. 10, No. 2

Tilakdharee, N., Ramidial, S., \& Parumasur, S. B. (2010). The relationship between job insecurity and burnout. South African Journal of Economic and Management Sciences, 13(3), 254-271. https://doi.org/10.4102/sajems.v13i3.103

Weber, A., \& Jaekel-Reinhard, A. (2000). Burnout syndrome: A disease of modern societies?. Occup. Med, 50(7). 512-517. https://doi.org/10.1093/occmed/50.7.512

Westman, M., Etzion, D., \& Danon, E. (2001). Job insecurity and crossover of burnout in married couples. Journal of Organizational Behaviour, 22, 467-481. https://doi.org/10.1002/job.91

William, D. R., Tahira, M. P., Swee-Lim, C., Cesar, M. M., \& Cornelius, J. K. (2010). The effects of job insecurity on job satisfaction, organizational citizenship behavior, deviant behavior, and negative emotions of employees. International Studies of Management \& Organization, 40(1), 74-91. https://doi.org/10.2753/IMO0020-8825400105

Yeves, J., Bargsted, M., Cortes, L., Merino, C., \& Cavada, G. (2019). Age and perceived employability as moderators of job insecurity and job satisfaction: A moderated moderation model. Frontiers Psychology, 10, 799. https://doi.org/10.3389/fpsyg.2019.00799

\section{Copyright Disclaimer}

Copyright for this article is retained by the author(s), with first publication rights granted to the journal.

This is an open-access article distributed under the terms and conditions of the Creative Commons Attribution license (http://creativecommons.org/licenses/by/4.0/). 